\title{
Cash Holdings and Over-Investments during Covid 19 Pandemic: The Evidence from Vietnam
}

\author{
Nhung Thi Tuyet Dao \\ Department of Business, Faculty of Language Education and Professional Development, VNU University of Languages and \\ International Studies, Vietnam National University, Hanoi, Vietnam
}

Received July 27, 2021; Revised September 24, 2021; Accepted October 17, 2021

\begin{abstract}
Cite This Paper in the following Citation Styles
(a): [1] Nhung Thi Tuyet Dao, "Cash Holdings and Over-Investments during Covid 19 Pandemic: The Evidence from Vietnam," Universal Journal of Accounting and Finance, Vol. 9, No. 6, pp. 1273 - 1279, 2021. DOI: 10.13189/ujaf.2021.090607.
\end{abstract}

(b): Nhung Thi Tuyet Dao (2021). Cash Holdings and Over-Investments during Covid 19 Pandemic: The Evidence from Vietnam. Universal Journal of Accounting and Finance, 9(6), 1273 - 1279. DOI: 10.13189/ujaf.2021.090607.

Copyright@2021 by authors, all rights reserved. Authors agree that this article remains permanently open access under the terms of the Creative Commons Attribution License 4.0 International License

\begin{abstract}
Since the end of 2019, the world has been witnessing a severe Covid 19 pandemic. Right from the beginning, it reveals serious effects on many aspects of the economy. During this period, it is believed that firms tend to reduce their investments and therefore hold more cash to minimize potential risks. By studying 2,868 firm-year observations from non-financial listed firms in Vietnam from 2017 to 2020, this paper examines the impact of Covid 19 pandemic on cash holdings and overinvestment. Furthermore, the paper also makes the comparison between the cash holding level of overinvestment firms and non-overinvestment firms during Covid 19 pandemic. With the panel data, the research uses GLS, fixed effect, GMM and logit models to test appropriate regressions. The findings indicate that firms seem to have a tendency to hoard more cash and also reduce overinvestments during Covid 19 pandemic that are consistent with the theory of precautionary motive. This research further shows that overinvestment firms still reserve less cash than other firms during the pandemic. This paper contributes to the current literature with the investigation of both corporate cash holdings and overinvestment during the Covid 19 pandemic. However, the research time period is only from 2017 to 2020, which might be a limitation of this paper.
\end{abstract}

Keywords Cash Holdings, Cash Management, Covid 19 Pandemic, Inefficient Investment, Investment, Overinvestment

JEL Classification: G30, G31, G32

\section{Introduction}

Cash is considered the most liquid asset to help businesses be more proactive in financial decisions and reduce risks related to solvency. Related literature mentioned three main factors that affect cash holding decisions including transaction costs, speculation and hedging. Those are firstly developed by Keynes [15] and also broadened by other scholars such as Baumol [4], Miller and Orr [19], Myers and Majluf [20], and Jensen [13]. Generally, external fund sources such as issuing new debt or new equity normally require high flotation costs. Thus, available cash holdings can help to reduce those transaction costs, and also reduce the risk from liquidating assets to obtain needed funds. Moreover, cash is used for daily transactions and firms may have to face the fluctuation of free cash flow or financial difficulties $[21,18]$. For those reasons, an appropriate cash holding level can be a good protection for firms from unexpected events that need urgent payments. Keynes [15] also confirms the role of cash holding in speculation if there are any sudden chances of getting profit. Eventually, holding cash can bring many advantages as mentioned, but also including disadvantages if it is held too much. According to Kim et al. [16] and Opler et al. [21], a high cash reserve might lower profitability and also increase the volatility in free cash flow.

From above motives, it is concluded that cash holdings are a very important decision of any firm. An optimal level of cash reserve can minimize some risks related to high transaction costs, or payment of unexpected events, 
increase hedging for firms, and maintain an expected profitability. Therefore, in the context of the Covid 19 pandemic with more potential risks and uncertain projects, firms might tend to increase cash reserves and reduce investments to minimize the risk of loss. The reduction of investments can lead to a positive effect of lower over-investments. To confirm those statements, this study collects data of 717 firms and 2,868 firm-year observations from listed firms on the 2 stock exchanges of Vietnam including Ho Chi Minh and Hanoi stock exchanges from 2017 to 2020 to see if it is true that the Covid-19 epidemic has an impact on the decision of cash holdings, inefficient investments, and overinvestments.

This paper improves on existing literature by investigating cash holding level during Covid 19 pandemic with a further consideration of over-investments during this severe period. The research paper comprises 3 main parts presented in turn in the following section. The first part focuses on the study overview including Covid 19 pandemic in Vietnam and literature review. The second part is the methodology section. The third section is the empirical results and discussion.

\section{Covid 19 Pandemic, Literature Review and the Models}

\subsection{Covid 19 Pandemic}

In fact, there are many factors that affect the decision-making of how much cash should be held in business operations, they include both micro and macro factors. The Covid19 epidemic can be considered a great shock to the economy when it is directly affecting people's lives and health, causing more than 2.4 million deaths and more than 110 million infections worldwide (according to worldomester.info, updated on 18/02/2021). The outbreak caused many countries to take measures to limit the spread such as social isolation, closing many business and service establishments, closing borders with countries with epidemics, etc. All those measures are really effective to help curb the spread of the disease, but it also seriously affects people's lives and negatively affects the economy when all trade seems to be getting more and more difficult.

In Vietnam, since the first case of the disease appeared in early 2020, it has shaken people's psyche, turned life upside down, and made it more difficult for businesses when many social distancing methods were taken. Vietnam in 2020 is considered as one of the successful countries in controlling epidemic, when the world daily sees thousands and millions of new infections and new deaths. Vietnam as of the end of 2020, the total number of infections is just under 1500 , of which most are imported cases, a few are infections in the community. However, with the epidemic situation being very complicated in the world, it seems that it still has a great impact on the psychology and decisions of businesses when the epidemic situation may still have a lot of negative impacts on the economy.

Based on the above facts, this study will examine how the epidemic factor affects the decision-making about cash holdings of enterprises. With the perception that the epidemic can make businesses more timid in investment decisions, and afraid of more risks, that more cash can be hoarded, also help to reduce inefficient and over investments.

\subsection{Motives of Cash Holdings}

There are three motives suggesting the level of cash holdings for any firm comprising transaction costs, hedging and speculative opportunities [15]. For transaction cost motives, cash is a convenient medium of exchange for day-to-day transactions or other assets [4]. Firm that has insufficient cash reserves might have to liquidate its illiquid assets or obtain external capitals with very high flotation costs when it needs more funds; thus, might lead to a lower profit or underperformance results. Furthermore, cash can help to minimize risks by prompt cash for any unexpected events such as financial distress. Therefore, it can be said that cash is a kind of hedging for firms [24]. At last, an appropriate cash reserve can create opportunities of getting higher earnings as speculation [2].

Literally, the cost of holding cash can be thought of as the difference between the income from holding cash and the costs that companies have to pay to raise more external capital. Hence, firms tend to consider the trade-off between the costs and benefits of holding cash to decide an appropriate level. Normally, firms with high investments tend to hold less cash. But in an uncertain situation of the economy such as Covid 19 pandemic, firms might reduce their investments and hold more cash based on the precautionary motive theory.

Look at the previous literature; there have been many factors considered affecting the decision of cash holdings. This paper, therefore, introduces the models of the following variables that are used popularly.

\subsection{Covid 19 Pandemic}

Covid 19 epidemic can be seen as a macro factor that creates uncertainty among all aspects of society. The uncertainty in the economy can create a high volatility of firm cash flows and profitability. According to Opler et al. [21], Almeida et al. [3], and Bliss et al. [6], under the negative impact of macroeconomic factors, firms tend to hold more cash to minimize risks related to unanticipated and unfavourable events. Combined with the theory of precautionary motives; this paper expects that there is a positive relationship between Covid 19 epidemic and cash holdings. Therefore, the first hypothesis is as follows: 


\section{H1: Firms tend to hold more cash during Covid 19 epidemic}

The following models are also constructed based on the hypothesis:

$$
\begin{gathered}
\text { CASHHOLD }_{\mathrm{it}}=\alpha_{0}+\alpha{ }_{1} \text { Covid19 }_{\mathrm{it}}+ \\
+\sum_{i}^{t} \beta \mathrm{X}_{\mathrm{it}}+d_{t}^{s} 1_{i, t}^{s}+\varepsilon_{i, t}
\end{gathered}
$$

Where the $1_{i, t}^{s}$ are sector indicators to control for industry effects. Explanatory variables include Covid19, leverage, ROA, dividend, firm size and Beta.

\subsection{Over-Investment}

Any economic shocks can slowdown economic activities, in which investment and cash holdings are two key factors that are examined in this paper. According to Abel and Eberly [1], Cooper and Haltiwanger [9], and Bloom et al. [7], investment is significantly lower during crisis or economic uncertainty. Moreover, according to Opler et al. [21], firms hold liquid assets to maintain planned investments when actual cash flows are too low relative to projected cash flows. During Covid 19 epidemic, all planned projects might be affected and lead to a high volatility of cash back. Therefore, based on the theory of precautionary motive, it is predicted that during the Covid 19 pandemic, firms tend to decrease investments, and therefore decrease overinvestment.

Therefore, there is a hypothesis and model developed as follows.

\section{H2: Firms tend to decrease overinvestment during Covid} 19 pandemic

$$
\begin{aligned}
& \text { Overinvest }_{\mathrm{it}}=\alpha_{0}+\alpha{ }_{1} \text { Covid19 }_{\mathrm{it}}+ \\
& +\sum_{i}^{t} \beta \mathrm{X}_{\mathrm{it}}+d_{t}^{s} 1_{i, t}^{s}+\varepsilon_{i, t}
\end{aligned}
$$

Where the $1_{i, t}^{s}$ are sector indicators to control for industry effects. The explanatory variables include Covid 19, Cash, leverage, ROA, dividend, and firm size.

\subsection{Cash Holdings in Overinvestment Firms during Covid 19}

Furthermore, this paper examines cash holding levels in over-investment firms. It is expected that, during Covid 19 pandemic, over-investment firms might still have lower cash levels than others due to heavy investments before the pandemic.

H3: Cash holdings is still lower in over-investment firms during Covid 19 pandemic

$$
\begin{aligned}
& \text { CASHHOLD }_{\mathrm{it}}=\alpha_{0}+\alpha_{1}\left(\text { Covid19 }_{\mathrm{it}}{ }^{*} \text { Overinvest }_{\mathrm{it}}\right)+ \\
& \sum_{i}^{t} \beta \mathrm{X}_{\mathrm{it}}+d_{t}^{s} 1_{i, t}^{s}+\varepsilon_{i, t}
\end{aligned}
$$

Where the $1_{i, t}^{s}$ are sector indicators to control for industry effects. The explanatory variables include Covid
19 times overinvestment firms represent for overinvested firms in Covid 19, leverage, ROA, dividend, firm size, and Beta.

\section{Data Source and Construction of Variables}

\subsection{Data Collection}

The data are annual data and collected from Thomson Reuter EIKON and annual reports of non-financial firms that include 717 non-financial companies with 2,868 firm-year observations listed on two stock exchanged markets of Vietnam is HNX and HOSE with a period of 4 years from 2017 to 2020 . The reason why this paper just focuses on the 4-year period is due to the main purpose of this paper is to examine the impact of Covid 19 on cash holding and in relation with investment. The period of 2017 to 2019 witnessed a stable increase with no significant volatility in GDP growth, it is considered a good period to make the research before the high volatility of 2020 with Covid 19. The period of 2017 to 2020 is expected to reflect good regression results. In order to avoid outliers, the author winsorized the data at the $1 \%$ level.

\subsection{Empirical Models}

The construction of all variables for cash holding models is as follows.

\section{CASHOLD}

There are many proxies used to represent cash holding variables, however this paper is based on the paper of Guney et al. [12] that used cash and short-term securities investments on total assets to represent the cash variable.

\section{Overinvestment}

Based on the paper of Biddle et al. [5], this paper constructs the proxy for inefficient investment by taking a regression of the dependent variable of capital expenditure on sale growths. Capital expenditure is calculated by total fixed assets divided by lagged total assets. After that, the residuals are used to estimate inefficient investment levels. For the overinvestment variable, four quartiles at $25^{\text {th }}$ percentile, $50^{\text {th }}$ percentile, and $75 \%$ percentile are identified after getting the residuals. It is stated that firms fall into the highest quartile are seen as overinvestment firms. Therefore, overinvestment is a dummy variable with 1 is represented for overinvestment firms and otherwise 0 .

\section{Covid 19}

Covid 19 is a dummy variable; 1 is represented for year 2020 with Covid 19 pandemic, and otherwise 0. 


\section{Leverage}

Kim et al. [16], Opler et al. [21], and Gamba and Triantis [11] state that firms with high debt in capital structure could reduce cash reserves, because it is an alternative fund for cash. Leverage is also used in the paper's model that is expected to show that there is a negative relationship between cash holdings and leverage. Leverage is measured as the ratio of total debt to total assets [23].

Profitability - ROA

According to Fresard [10], firms with strong return on assets tend to hold more cash to take the advantages from cash reserves. This paper also predicts that cash holdings increase when ROA increases.

\section{Dividend}

Findings from previous studies suggest that a high dividend distribution leads to lower cash levels [21]. However, Ozkan and Ozkan [22] state that dividend-paying firms need sufficient cash holdings, hence tend to hold more cash. Therefore, this study will re-examine the effect of dividends on cash holdings. The dividend variable is measured as the ratio of the total value of dividend payments divided by the total profit after tax.

\section{Firm size}

Based on the research by Guney et al. [12], this paper investigates the effect of firm size, as measured by the natural logarithm of total sales, on cash holdings. As it is stated that large firm might be easier to access diversified funds than others, hence might hold less cash than firms with difficulty of accessing external funds.

\section{Beta}

In addition to the above factors, this study also considers the impact of systematic risk, namely Beta - a measure of the risk of firms compared to the average market. Under the impact of systematic risk to examine the impact on the amount of cash held.

For overinvestment models, all explanatory variables are developed from investment models researched previously, such as it is expected that there is a significant relationship between overinvestment and leverage [25]; a positive impact related to profitability [8,17]; also the significant relationship with dividend and firm size [14].

\section{Empirical Results and Discussion}

\subsection{Statistical Description}

Table 4.1 summarizes information about the observations. It can be seen that cash accounts for $0.1 \%$ at the lowest level, and $36.5 \%$ at the highest level in total assets, the average cash held is about $13.1 \%$. Regarding leverage, there are some firms without debt in the capital structure, while the maximum debt is up to $48.43 \%$. For ROA variable, in the study period, the minimum value is $0.12 \%$, and the highest one is $13.55 \%$. Dividends paid were recorded from no dividend-paying firms, and dividend-paying firms with the highest dividend payment were about $38.9 \%$ of the profit. Regarding the size of the firm calculated by the natural logarithm of total sales, the value shows a range from 10.88 and 12.74. Beta fluctuates between -0.14 and 1.04 with an average beta of 0.364 .

Table 4.1. Statistical Description

\begin{tabular}{cccccc}
\hline VARIABLES & $\mathbf{N}$ & Mean & SD & Min & Max \\
\hline Covid19 & 2,868 & 0.250 & 0.433 & 0 & 1 \\
CASHHOLD & 2,868 & 0.131 & 0.117 & 0.009 & 0.365 \\
Leverage & 2,868 & 20.42 & 16.95 & 0 & 48.43 \\
ROA & 2,868 & 5.132 & 4.380 & 0.120 & 13.55 \\
Dividend & 2,868 & 0.187 & 0.171 & 0 & 0.389 \\
Firmsize & 2,868 & 11.81 & 0.592 & 10.88 & 12.74 \\
Beta & 2,868 & 0.364 & 0.382 & -0.140 & 1.040 \\
\hline
\end{tabular}

Note: All variables are winsorized at the $1 \%$ and $99 \%$ percentiles.

\subsection{Correlation Matrix}

The correlation matrix shows that Covid-19 epidemic has an impact that makes firms tend to hoard more cash. This is consistent with predictions. Besides, leverage, firmsize and beta might have a negative relationship with cash holdings; meanwhile, ROA and dividend are shown to have a positive impact on cash holdings. The results are clarified and confirmed with the following tests.

Table 4.2. Correlation matrix

\begin{tabular}{|c|c|c|c|c|c|c|}
\hline & CASHHOLD & Covid19 & Leverage & ROA & Dividend & Firmsize \\
\hline CASHHOLD & 1 & & & & & \\
\hline Covid19 & 0.013 & 1 & & & & \\
\hline Leverage & -0.422 & -0.004 & 1 & & & \\
\hline ROA & 0.354 & -0.068 & -0.287 & 1 & & \\
\hline Dividend & 0.308 & -0.092 & -0.184 & 0.355 & 1 & \\
\hline Firmsize & -0.004 & -0.003 & 0.328 & 0.124 & 0.122 & 1 \\
\hline Beta & -0.076 & 0.061 & 0.023 & -0.034 & -0.119 & 0.245 \\
\hline
\end{tabular}

Note: This table reports the Pearson correlations based on the 717 firms and 2,868 firm-year observations. All variables are winsorized at the $1 \%$ and $99 \%$ percentiles 


\subsection{Empirical Results and Discussion}

The study uses panel data for analysis, so both fixed effect and random effect models are used. Then test again with the Hausman test and see that the suitable model is the fixed effect model. Furthermore, the results of general least square regression for panel data are also represented. Table 4.3 shows the regression results of the fixed effect model, GLS and GMM for robustness check. The use of the two-step system-generalized method of moments (GMM) estimation method is for the dynamic panel-data predictions. This method is useful in controlling for the potential endogeneity, simultaneity, firm-level heterogeneity and it addresses the dynamic nature of the cash holding management of firms.

Table 4.3. Covid 19 pandemic and Cash holdings model

\begin{tabular}{|c|c|c|c|}
\hline & (1) & (2) & (3) \\
\hline VARIABLES & GLS & Fixed & GMM \\
\hline \multirow[t]{2}{*}{ Covid19 } & $0.012 * *$ & $0.004 *$ & $0.016^{* *}$ \\
\hline & $(0.005)$ & $(0.003)$ & $(0.005)$ \\
\hline \multirow[t]{2}{*}{ Leverage } & $-0.003 * * *$ & $-0.001 * * *$ & $-0.003 * * *$ \\
\hline & $(0.001)$ & $(0.001)$ & $(0.001)$ \\
\hline \multirow[t]{2}{*}{ ROA } & $0.005 * * *$ & $0.002 * * *$ & $0.003 * * *$ \\
\hline & $(0.001)$ & $(0.001)$ & $(0.001)$ \\
\hline \multirow[t]{2}{*}{ Dividend } & $0.112 * * *$ & $-0.019 *$ & $0.243 * * *$ \\
\hline & $(0.013)$ & $(0.011)$ & $(0.034)$ \\
\hline \multirow[t]{2}{*}{ Firmsize } & $0.019 * * *$ & $0.032 * * *$ & $0.014 * *$ \\
\hline & $(0.004)$ & $(0.009)$ & $(0.006)$ \\
\hline \multirow[t]{2}{*}{ Beta } & $-0.022 * * *$ & -0.003 & -0.012 \\
\hline & $(0.006)$ & $(0.005)$ & $(0.007)$ \\
\hline \multirow[t]{2}{*}{ Constant } & $-0.082 *$ & $-0.219 * *$ & -0.038 \\
\hline & $(0.045)$ & $(0.106)$ & $(0.061)$ \\
\hline Observations & 2,868 & 2,868 & 2,868 \\
\hline R-squared & & & 0.233 \\
\hline Wald & $950.55 * * *$ & & \\
\hline F-test & & $13.37 * * *$ & $117.21 * * *$ \\
\hline $\begin{array}{l}\text { Number of } \\
\text { firms }\end{array}$ & 717 & 717 & 717 \\
\hline
\end{tabular}

Note: The dependent variable is cash holdings. The asterisk * (**)

(***) indicates significant level at the $10 \%, 5 \%$, and $1 \%$ level, respectively. Industry level is also tested.

It is obviously seen that the Covid 19 epidemic makes firms increase cash holdings. During this time, firms tend to hold more cash than before. It seems that the fear of economic uncertainty due to Covid 19 forces firms to think about precautionary motives. To strengthen the results, three models were constructed and showed similar significant results. Those results are consistent with the precautionary theory $[15,24]$; predictions and relevant literature $[3,6,21]$. Cash held more during the period of an uncertain economy helps to reduce potential risks such as fluctuations of cash flows, unexpected events or shortage of capital. Furthermore, those risks might increase the cost of using capital if firms need to raise funds in urgent cases. Therefore, it is understandable if there is a trend of increasing cash holdings during Covid 19 pandemic.

Yet, increasing cash holdings during uncertainty periods is understandable, when firms want to minimize potential risks. The increase of cash holdings and also decrease in investments due to Covid 19 pandemic might also lead to decrease in overinvestment. Models from table 4.4 confirm that statement. When investigating the model of overinvestment, the results suggest that during the period of Covid 19, overinvestment seems to be reduced. To support the conclusion, model (6) uses logit regression to re-check the results, because the variable of overinvestment is a binary variable.

Table 4.4. Overinvestment models

\begin{tabular}{|c|c|c|c|}
\hline & (4) & (5) & (6) \\
\hline VARIABLES & GLS & Fixed & logit \\
\hline \multirow[t]{2}{*}{ Covid19 } & $-0.242 * * *$ & $-0.246^{* *}$ & $-1.143^{* * *}$ \\
\hline & $(0.021)$ & $(0.019)$ & $(0.102)$ \\
\hline \multirow[t]{2}{*}{ Cash } & $-0.253 * * *$ & $0.611 * * *$ & $-1.156^{* * *}$ \\
\hline & $(0.086)$ & $(0.171)$ & $(0.395)$ \\
\hline \multirow[t]{2}{*}{ Leverage } & $0.005 * * *$ & $0.007 * * *$ & $0.021 * * *$ \\
\hline & $(0.001)$ & $(0.001)$ & $(0.002)$ \\
\hline \multirow[t]{2}{*}{ ROA } & $0.019 * * *$ & $0.025 * * *$ & $0.085 * * *$ \\
\hline & $(0.002)$ & $(0.004)$ & $(0.010)$ \\
\hline \multirow[t]{2}{*}{ Dividend } & $0.106^{*}$ & 0.038 & $0.480 *$ \\
\hline & $(0.056)$ & $(0.083)$ & $(0.255)$ \\
\hline \multirow[t]{2}{*}{ Firmsize } & $-0.094 * * *$ & $-0.315 * * *$ & $-0.428 * * *$ \\
\hline & $(0.016)$ & $(0.067)$ & $(0.075)$ \\
\hline \multirow[t]{2}{*}{ Constant } & $1.412 * * *$ & $3.849 * * *$ & $4.161 * * *$ \\
\hline & $(0.187)$ & $(0.786)$ & $(0.856)$ \\
\hline Observations & 2,868 & 2,868 & 2,868 \\
\hline R-squared & & 0.108 & \\
\hline Wald & $294.47 * * *$ & & \\
\hline F-test & & $43.47 * * *$ & \\
\hline LR & & & $284.44 * * *$ \\
\hline $\begin{array}{c}\text { Number of } \\
\text { firms }\end{array}$ & 717 & 717 & 717 \\
\hline $\begin{array}{l}\text { Note: The depen } \\
(* * *) \text { indicates } \\
\text { respectively. Ind }\end{array}$ & $\begin{array}{l}\text { variable is } \\
\text { ficant leve }\end{array}$ & vestment. & $\begin{array}{l}\text { sterisk } *(* *) \\
\text { nd } 1 \% \text { level, }\end{array}$ \\
\hline
\end{tabular}

A further investigation about cash holdings in overinvestment firms during Covid 19 epidemic can be a more detailed explanation of cash holdings. Firms with poor corporate management might hold less cash to invest more, especially, invest in high-risk projects. However, risks from the unstable economy might make all firms become more careful and reduce overinvestment as the results from model (7), (8), and (9) confirms. However, with overinvestment firms, the change in the cash holding 
behaviour might be smaller than others. The empirical regression result supported that prediction with significant results and shows that during Covid 19 period, firms with overinvestment still held less cash than others.

Table 4.5. Examining Cash holdings in overinvestment firms during Covid 19 pandemic

\begin{tabular}{|c|c|c|c|}
\hline & (7) & (8) & (9) \\
\hline VARIABLES & GLS & Fixed & GMM \\
\hline \multirow[t]{2}{*}{ Covid*Overinvest } & $-0.018 * *$ & $-0.010^{*}$ & $-0.018 * *$ \\
\hline & $(0.009)$ & $(0.006)$ & $(0.008)$ \\
\hline \multirow[t]{2}{*}{ Leverage } & $-0.003 * * *$ & $-0.001 * * *$ & $-0.003 * * *$ \\
\hline & $(0.001)$ & $(0.001)$ & $(0.001)$ \\
\hline \multirow[t]{2}{*}{ ROA } & $0.005^{* * *}$ & $0.002 * * *$ & $0.003 * * *$ \\
\hline & $(0.001)$ & $(0.001)$ & $(0.001)$ \\
\hline \multirow[t]{2}{*}{ Dividend } & $0.110 * * *$ & $0.022 * *$ & $0.245 * * *$ \\
\hline & $(0.013)$ & $(0.011)$ & $(0.034)$ \\
\hline \multirow[t]{2}{*}{ Firmsize } & $0.019 * * *$ & $0.032 * * *$ & $0.013 * *$ \\
\hline & $(0.004)$ & $(0.009)$ & $(0.005)$ \\
\hline \multirow[t]{2}{*}{ Beta } & $-0.021 * * *$ & -0.002 & -0.009 \\
\hline & $(0.006)$ & $(0.005)$ & $(0.007)$ \\
\hline \multirow[t]{2}{*}{ Constant } & $-0.075^{*}$ & $-0.218 * *$ & -0.029 \\
\hline & $(0.045)$ & $(0.106)$ & $0.061)$ \\
\hline Observations & 2,868 & 2,868 & 2,868 \\
\hline R-squared & 0.043 & & 0.230 \\
\hline Wald & $984.01 * * *$ & & \\
\hline F-test & & $13.47 * * *$ & $119.34 * * *$ \\
\hline Number of firms & 717 & 717 & 717 \\
\hline
\end{tabular}

\section{Conclusion}

Based on 717 non-financial listed firms in Vietnam with 2,868 firm-year observations, all models showed significant results and support for the paper hypothesis.

Through regression models and empirical results, it can be concluded that the Covid-19 epidemic has a positive impact on cash holdings. The results are consistent with theory, literature and predictions. Such during the high risky period, firms should be more cautious by reducing investments; increase cash reserves to maintain the stable liquidity. Hence, it also might help firms reduce overinvestments. The paper also indicates that firms with overinvestment still hold less cash than other firms.

The limitations of this paper include the short data set might not provide strong evidences about the findings; the industry is just divided in three areas consisting of service, manufacturing and merchandise, but not more specific industries, because, during the pandemic, some firms might perform better than others such as technology firms, so the cash holdings of those firms might be different than others. Further studies might address those limitations.

\section{REFERENCES}

[1] Abel, A. and J. Eberl, "Optimal Investment With Costly Reversibility," Review of Economic Studies 63,4, 581-593, 1996, https://doi.org/10.2307/2297794

[2] Al-Najjar, B. \& Belghitar, Y, "Corporate cash holdings and dividend payments: evidence from simultaneous analysis," Managerial and Decision Economics, 32, 4, 231-241, 2011, https://doi.org/10.1002/mde.1529

[3] Almeida, H., Campello, M., Weisbach, M.S., "Cash flow sensitivity of cash," Journal of Finance, 59, 1777-1804, 2004, https://doi.org/10.1111/j.1540-6261.2004.00679.x

[4] Baumol, W.J., "The transactions demand for cash: an inventory theoretic approach," Quarterly Journal of Economics, 65, 545-556, 1952, https://doi.org/10.2307/1882 104

[5] Biddle, G. C., Hilary, G., \& Verdi, R. S., "How does financial reporting quality relate to investment efficiency?," Journal of Accounting and Economics, 48, 2-3, 112-131. 2009, https://doi.org/10.1016/j.jacceco.2009.09.001

[6] Bliss, B. A., Y. Cheng, and D. J. Denis, "Corporate Payout, Cash Retention, and the Supply of Credit: Evidence from the 2008-2009 Credit Crisis," Journal of Financial Economics, 115, 3, 521-540, 2015, https://doi.org/10.1016/j.jfineco.2014.10.013

[7] Bloom, N., S. Bond, and J. Van Reenen, "Uncertainty and Investment Dynamics," Review of Economic Studies, 74, 391-415, 2007, https://doi.org/10.1111/j.1467-937X.2007. 00426.x

[8] Calcagnini, G., Ferrando, A., \& Giombini, G., "Multiple market imperfections, firm profitability and investment," European Journal of Law and Economics, 40, 1, 95-120, 2014, doi:10.1007/s10657-014-9454-Z

[9] Cooper, R. W. and J. C. Haltiwanger, "On the Nature of Capital Adjustment Costs," Review of Economic Studies 73, 3, 611-633, 2006, https://doi.org/10.1111/j.1467-937X.20 06.00389.x

[10] Fresard, L., "Financial strength and product market behavior: the real effects of corporate cash holdings," Journal of Finance, 65, 3, 1097-1122, 2010, https://doi.org/10.1111/j.1540-6261.2010.01562.x

[11] Gamba, A. \& Triantis, A., "The value of financial flexibility," Journal of Finance, 63, 5, 2263-2296, 2008, https://doi.org/10.1111/j.1540-6261.2008.01397.x

[12] Guney, Y., Ozkan, A., \& Ozkan, N., "International evidence on the non- linear impact of leverage on corporate cash holdings," Journal of Multinational Financial Management, 17, 1, 45-60, 2007, https://doi.org/10.1016/j. mulfin.2006.03.003

[13] Jensen, M.C., "Agency costs of free cash flow, corporate finance, and takeovers," American Economic Review, 76, 2, 323-329, 1986, https://www.jstor.org/stable/1818789 
[14] Kadapakkam, P.-R., Kumar, P. ., \& Riddick, L. A., "The impact of cash flows and firm size on investment: The international evidence. Journal of Banking \& Finance, 22, 3, 293-320, 1998, doi:10.1016/s0378-4266(97)00059-9

[15] KEYNES, John Maynard. The general theory of employment, interest, and money: interest and money. Harcourt, Brace and company, 51, 4, 600-603, 1936, https://doi.org/10.2307/2143949

[16] Kim, C. S., Mauer, D. C., \& Sherman, A. E., "The determinants of corporate liquidity: theory and evidence, Journal of Financial and Quantitative Analysis, 33, 3, 335-359, 1998, https://doi.org/10.2307/2331099

[17] Masulis, R. W., \& Trueman, B., "Corporate Investment and Dividend Decisions under Differential Personal Taxation," The Journal of Financial and Quantitative Analysis, 23, 4, 369, 1988, doi: $10.2307 / 2331077$

[18] Mikkelson, W.H. and Partch, M.M., "Do persistent large cash reserves hinder performance?," Journal of Financial and Quantitative Analysis, 38, 2, 275-294, 2003, https://doi.org/10.2307/4126751

[19] Miller, M.H., \& Orr, D., "A model of the demand for money by firms," Quarterly Journal of Economics, 80, 3, 413-435, 1966, https://doi.org/10.2307/1880728
[20] Myers, S. C., \& Majluf, N. S., "Corporate financing and investment decisions when firms have information that investors do not have," Journal of Financial Economics, 13, 2, 187-221, 1984, https://doi.org/10.1016/0304-405X(84)9 0023-0

[21] Opler, T., Pinkowitz, L., Stulz, R., \& Williamson, R., "The determinants and implications of corporate cash holdings," Journal of Financial Economics, 52, 1, 3-46, 1999, https://doi.org/10.1016/S0304-405X(99)00003-3

[22] Ozkan, A., \& Ozkan, N., "Corporate cash holdings: an empirical investigation of UK companies. Journal of Banking \& Finance, 28,9, 2103-2134, 2004 https://doi.org/10.1016/j.jbankfin.2003.08.003

[23] Subramaniam, V., Tang, T. T., Yue, H., \& Zhou, X., "Firm structure and corporate cash holdings. Journal of Corporate Finance", 17, 3, 759-773, 2011, https://doi.org/10.1016/j.jc orpfin.2010.06.002

[24] Whalen, E.L., A rationalization of the precautionary demand for cash. Quarterly Journal of Economics, 80, 2, 314-324, 1966, https://doi.org/10.2307/1880695

[25] Xuan Vinh Vo , Leverage and Corporate Investment Evidence from Vietnam, Finance Research Letters, 28, 2018, doi: 10.1016/j.frl.2018.03.005 